\title{
Revitalization of the Penitentiary Complexes in the Historic Centre of Florence
}

\author{
Ekaterina Tribelskaya ${ }^{1, *}$
}

\author{
${ }^{1}$ Moscow State Academic Art Institute named after V. Surikov, Moscow, Russia \\ ${ }^{*}$ Corresponding author. E-mail: egtrib@gmail.com
}

\begin{abstract}
The project of revitalization of penitentiary institutions, occupying a significant part of Santa Croce for more than 100 years, is considered in the article. Particular attention is paid to the project of the social center created on the basis of the former Murate Prison complex. The history of these complexes formed on the basis of monasteries of the 15 th century is examined. The results of the project and the significance of the new multifunctional centre for the city are analyzed.
\end{abstract}

Keywords: architectural heritage, historic centre of Florence, revitalization of penitentiary institutions in Italy

\section{INTRODUCTION}

Santa Croce $^{1}-$ one of the districts of the historic centre of Florence. Dense medieval buildings are wellpreserved here. The proximity of such objects as Santa Maria del Fiore and Ponte Vecchio has been attracting a lot of tourists to this area for centuries who are not even aware of the social and cultural problems of the city. So few people know that at the end of the 20th century there were 3 active prisons in this area - Santa Teresa, Santa Verdiana и Murate ("Fig. 1"). These prisons were opened in the 70s of the XIX century and functioned until the 80 s of the XX century. Over the past century, the sad name "Prison Area" has established itself among the Florentines beyond this area.

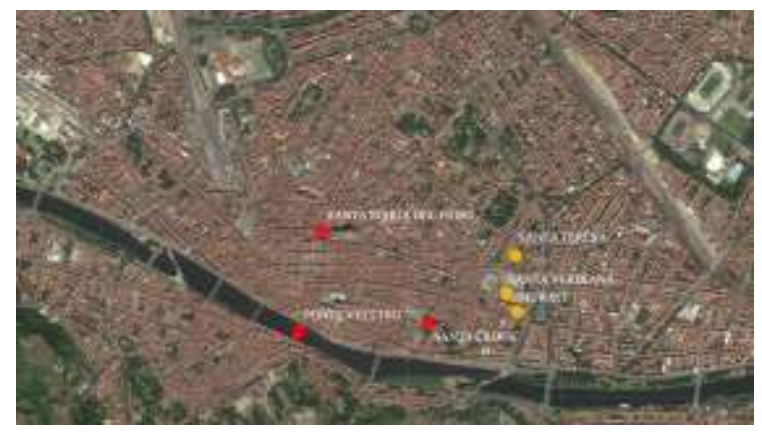

Fig. 1. A fragment of the plan of the historic part of Florence.

\section{THE HISTORY OF MONASTERIES BEFORE THE NAPOLEONIC REFORMS OF 1808}

But these objects were not always prisons. Santa Teresa, Santa Verdiana and Murate complexes were

All original names are in Italian. originally monasteries. Each of them had a long, rich, but tragic history.

Santa Teresa - the convent, named after St. Theresa of Avila, was founded in 1628. The monastery and church were designed by Giovanni Kokapani. The monastery lasted until 1808 [1].

In 1807, after the victories of Napoleon, the Grand Duchy of Tuscany was annexed to France. Following the emperor's desire to limit the power of the Catholic Church, in 1808 the monastery of Santa Teresa, together with 65 other religious institutions in Florence, was closed and their property was confiscated [2].

Later, after the French left Florence, the monastery was rebuilt and then finally disbanded in 1865. Later, a homeless shelter was opened at its base, which was managed and served by nuns. In 1866, it was temporarily transformed in a prison, but as a result, it remained a prison for many years.

In 1875 , certain work was carried out to adapt and expand the buildings for the needs of the penitentiary institution. The facility was badly damaged by the flood in $1966^{2}$, but was restored and functioned as a prison until 1974.

Santa Verdiana Monastery was founded in 1395 by the notary Niccolo Manetto di Buonagiunta for the nuns of the Order of Vallombrosane. The monastery was named after san Giovanni Gualberto (995-1073) and Santa Verdiana (1182-1242), but eventually only the name Santa Verdiana remained. After a five-year restoration of the existing building and the construction

\footnotetext{
During the flood of November 4, 1966, the water level in the streets of Florence reached 3 meters.
} 
of the church, the first nuns arrived. In 1402, the monastery was taken under the protection of the Republic of Florence, and in 1425 the second stage of construction began. Three centuries of serene life passed in the monastery [3].

In 1808, the monastery of Santa Verdiana was closed for the same reason as Santa Teresa, and its' property was also confiscated.

It was planned to arrange a city slaughterhouse on the territory of the monastery. Fortunately, this was avoided, as the French left Italy after Napoleon's abdication in April 1814. For a while, the nuns reappeared here.

In 1865, after the closure of Stinche, an old city prison [4], the government was allowed to take over the monastery for temporary use as a women's prison. Therefore, the monastery was finally closed, and significant changes were made to its interior. However, what was intended only for the temporary placement of prisoners soon became permanent. Gradually, the monastery of Santa Verdiana was adapted to maintain prisoners and turned into a women's prison.

The convent Murate. The history of the monastery began in 1390 with the fact that a young woman named Apollonia began to live in complete solitude in a small hut near the second pylon of the Ponte Rubaconte (modern name Ponte alle Grazie). After six years of living alone, Apollonia took another woman, her sister Agatha and her three-year-old granddaughter. In 1400, feeling the need to completely shield themselves from the world, they closed tightly in their small hut (practically walled themselves up) and lived on alms in conditions of extreme deprivation. Soon, other women followed suit and took a hut near another pylon. People of that time, struck by such a radical choice, began to call them «Murate» ${ }^{3}$. In 1420 , the number of sisters in captivity increased to 13. Pope Martino V, passing through Florence, was struck by such sacrifice and gave them his blessing [5]

In 1424, the abbot Gomezio Benedettino, appointed pope reformer of all the monasteries of Florence, pledged to defend the spiritual interests of the Murate sisters, and on December 13 solemnly transferred them to Via Ghibellina into a house inherited from local benefactors, which was adapted for a small monastery. The name Murate was subsequently assigned to the monastery. In 1434, Pope Eugenio IV established a direct dependence of Murate on Rome. It was a privilege that attracted attention to the monastery and increased its prestige. The number of sisters grew rapidly and soon the existing building became very crowded.
Between 1439 and 1443, a new monastery was built under the patronage of Giovanni di Amerigo Benci del Sanna, a member of the merchant family, which, like other noble families in Florence, invested in urban construction to establish his prestige $[6]^{\mathrm{p} .3}$.

In 1464, other benefactors donated gardens, land, and houses adjacent to the monastery. Subsequently, many wealthy Florentines made their generous donations. After a fire in 1471, the monastery was rebuilt and expanded by Lorenzo Medici. From the second half of the fifteenth century and throughout the sixteenth century, the daughters of the most prominent Italian families of that time were accepted in the monastery.

In 1557, there were victims among the nuns as a result of the flood, and the monastery was badly damaged: the walls of the garden and the church were destroyed, besides, precious interior items, paintings, and books were lost. The bust with the image of Mary and Baby Jesus, created by Desiderio da Settignano was saved. Later, it was credited with "amazing miracles", which attracted many parishioners to the monastery with rich donations, which made it possible to build a new chapel in 1587 Sanctae Mariae ad Nives, inside of which was placed a wonderful marble bust, an object of worship and donations [6] ${ }^{\mathrm{p} .7}$. By the end of the 18th century, Murate was one of the largest and richest Florentine monasteries.

Its end was determined by the suppression of religious corporations by the French government. At the time of the final closure in 1817, 246 sisters were present at the monastery. Further, the monastery complex was waiting for a sad fate.

In 1815, the Austro-Hungarian troops landed in Murate, passing through Rome, to participate in the Austro-Neapolitan war. In 1817, part of the building was assigned to Pia Casa del Lavoro, and part was used as private houses [6, p.16]. After 1827, the church was rented as a workshop by sculptor Lorenzo Bartolini with the following desecration. Later, until 1845, the complex housed barracks and a fireworks factory [7]

It can be seen from the foregoing that all three prosperous monasteries were liquidated as institutions at the beginning of the 19th century as a result of Napoleonic reforms and never regained their existence after the French left Italy.

\section{CREATION OF PENITENTIARY COMPLEXES ON THE BASIS OF MONASTERIES}

After a forty-year hiatus, in 1866, almost at the same time, the city authorities of Florence decided to use the complexes of the former monasteries as penitentiary complexes. This decision was associated 
with the closure of the old Florentine prison Stinche, built in 1299 [4].

A powerful structure surrounded by a moat did not accommodate a large number of prisoners by this time, also, according to the new requirements of that time, it was not necessary to contain persons who committed serious crimes, debtors (creditors) and political prisoners.

Obviously, the monastery complexes were not accidentally chosen for these purposes: closeness to the city (all monasteries overlooked the city with almost blank walls) and their planning structure were very suitable for the requirements of the prison and could be adapted to new functions without significant costs. What happened to Santa Teresa and Santa Verdiana.

Unlike the previous two complexes, a large-scale reconstruction was carried out in Murate ("Fig. 2")
Work began on strengthening the outer wall of the monastery. Following the new prison policy formulated by Cesare Beccaria [8] and penal reforms, the architect Domenico Giraldi developed an innovative project aimed at the implementation of an inspection-type prison, which required only a few jailers to control many prisoners [9].

The project included separate cells for adult prisoners, while minors were detained in the same laboratory environment. Under the new reform, Murate carried out activities for the re-education and training of prisoners (captives). Spiritual assistance was entrusted to two clergymen $[10]^{\mathrm{p} .8}$. In 1843 , a printing house was opened on the territory of the prison. Subsequently, other extensions were carried out ("Fig. 2"). From January 1, 1837 to January 1, 1843, 560 prisoners were held here $[10]^{\mathrm{p} .6}$. Murate Prison functioned until 1986.

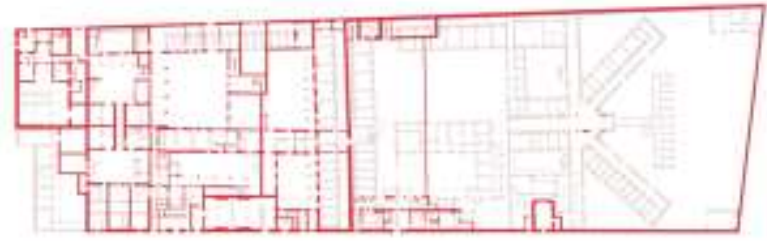

$1424-1832$

Plan of the convent MURATE

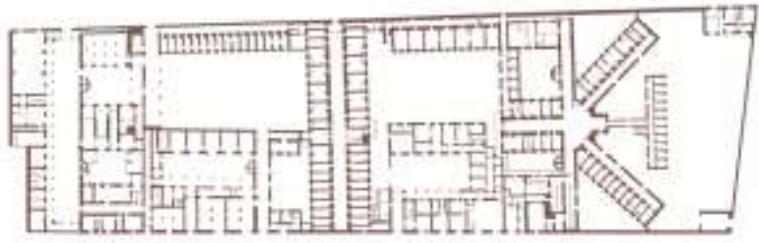

$1898-1983$

Plan of the MURATE Prison

Fig. 2. Plan of Murate complex before and after the reconstruction.

By the 70s of the 20th century, all 3 prisons were overcrowded and completely did not meet sanitary requirements. All buildings were significantly affected during the flood of 1966, were in almost emergency condition. Riots arose among the prisoners.

In 1984, after the construction and commissioning of the new Sollicciano penitentiary complex outside of Florence, the release of prisons Santa Tereza, Santa Verdiana and Murate began.

However, the vacated buildings and their territories remained abandoned and closed to the city for more than 10 years.

\section{PROJECT AND IMPLEMENTATION OF THE REVITALIZATION OF PENITENTIARY COMPLEXES SANTA TEREZA, SANTA VERDIANA AND MURATE}

In 1986, as part of a major reconstruction project for the Santa Croce area, an international competition for ideas on the new use of vacated buildings was announced, the results of which were shown at an exhibition in the Santa Verdiana complex in the fall of 1988 [11]

In 1998, the City Council of Florence approved a project for the revitalization of vacated prison complexes, developed by the Municipality of Florence. The most ambitious and significant for the city was the Murate Prison Revitalization Project. Later, the name 
Murate was decided to retain after the revitalization of the prison complex for the new urban social centre of Florence.

In 1982, the Murate penitentiary complex was declared a World Heritage Site, and the Municipality of Florence decided to use the preliminary contribution of UNESCO, involving architect Renzo Piano as a goodwill ambassador for architecture and urban environment - UNESCO, which allowed him to take part in the project [12].

Renovation of the Murate complex began in 2001. The project was called "Inspiration." The decisions were aimed at the implementation of various functions: residential, public, educational, commercial, craft, social. The authors of the complex project were guided by the following basic principles [13]:

- "City-fortress" in the city;

- Layering project: public, commercial, craft and social environment on the ground floor; offices and residential buildings on the upper floors;

- Maximum permeability on the ground floor, opening to the city;

- The principle of humanization;

- The principle of preserving the memory of the place;

- The principle of multifunctionality;

- The principle of the new architecture.

In addition to the construction of public housing, a large number of city functions had to be integrated into

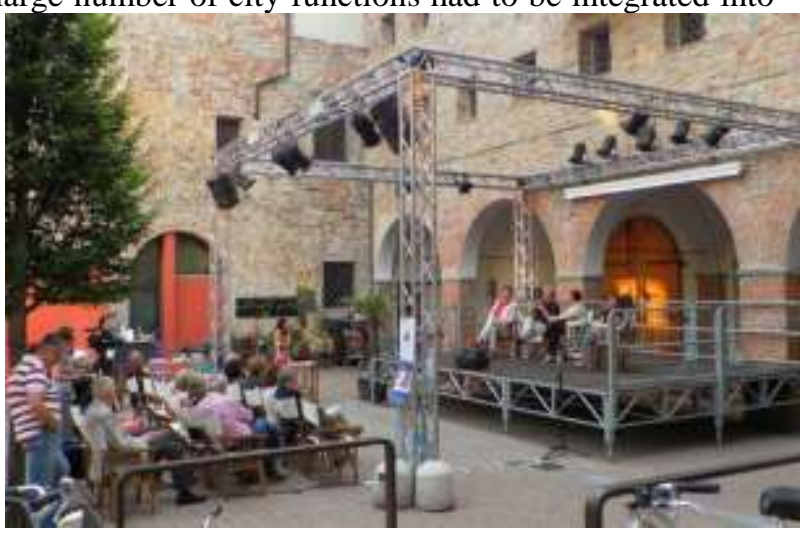

a the complex, to give the project flexibility and to provide the opportunity to modify it in the future.

The total project area is 2700 square meters, with 45 apartments and a pedestrian zone.To create the greatest accessibility and openness of the complex for the city, the lower floor (ground level) includes public spaces: a literary cafe, including an open library and places for individual work; universal halls; small shops (book and souvenir); public library and exhibition hall. At the second level, premises are located around the entire complex, mainly providing social functions: offices, classes for various purposes, including computer rooms, coworking, etc. On the upper levels are residential apartments. The apartments are designed on the basis of the former cameras, by combining them, which made it possible to get many layout options: from small to medium. Residential floors have a gallery structure. The last blocks of the apartments were populated in 2018 [14]

The Piazza Madonna della Neve square, formed by the union of two courtyards, after the demolition of the existing auxiliary building, with an area of about 2000 square meters, is actually the heart of the complex and is open to the city. Another square of the complex, namely Piazza delle Murate, which overlooks the Literary Cafe, the universal hall and the library, has become a very popular meeting place for Florentines. In the warm season, cafe tables are brought there. Concerts of popular performers, attracting Florentines and guests of the city and other socially significant events, including the prestigious Firenze FilmCorti Festival are held there ("Fig. 3").

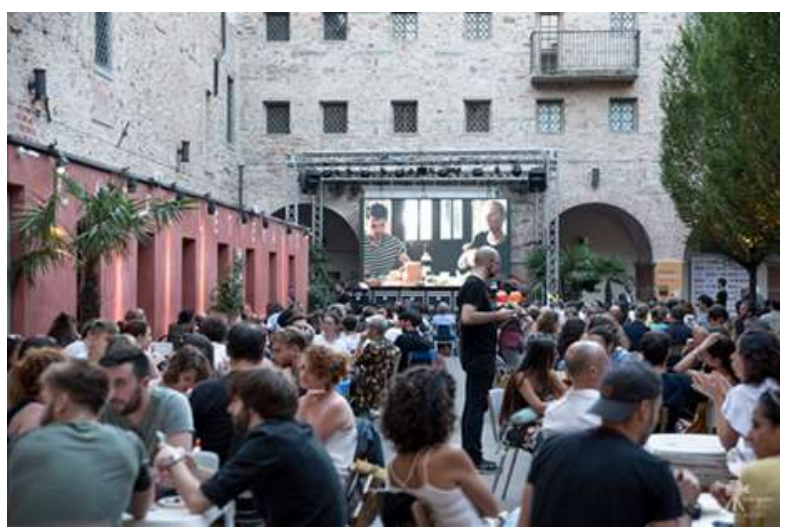

b

Fig. 3. Events at Piazza delle Murate.

a. a - An evening in memory of the dead sailors "February 1944. The massacre without public memory "July 11, 20134; b - 6th International Film Festival Firenze FilmCorti Festival ${ }^{5}$.

https://piroscafooria.it/blog/febbraio-1944-una-strage-senza-memoria-pubblica/

https://firenzefilmcortifestival.com/6-firenze-filmcorti-fest-tutti-i-film-ammessi-alle-giornate-finali/ 
Designers and builders extremely delicately reconstructed historical buildings, reacted very carefully to changing facades, and preserved many historical details of the interior space that look like art objects in the updated interior.

One of the attractions of the complex was the 70meter-long Vertical Garden (Giardino verticale) formed on a wall overlooking Young Italy Boulevard (viale Giovine Italia). It was created in 2013 and consists of modular panels that are filled with plants of different colors, blooming at different times of the year. Irrigation is provided by an automatic micro-irrigation system [15].
By 2016, part of the complex was mothballed, as due to a lack of means of work, they were suspended. However, in 2018, a new competition was held for the reconstruction and development of the part of the complex overlooking the avenue Viale della Giovine Italia. The area at the end of the complex has been used as a parking lot for many years. The conditions of the competition set the task of even more actively using the complex for the city, opening additional through (transit) passages through the complex not only from papal streets Via dell'Agnolo and Via Ghibellina, but also from Viale della Giovine Italia ("Fig. 4").

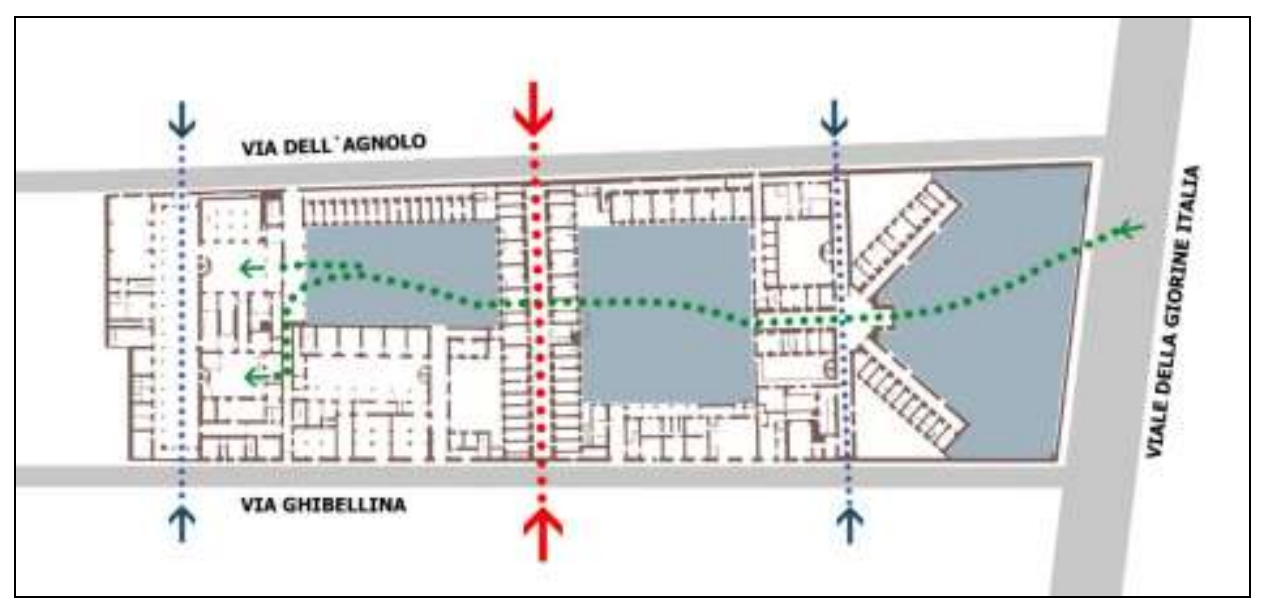

Fig. 4. The Murate complex "permeability" scheme.

The innovative nature of the Murate Prison Reuse Project was praised by experts and was recognized by the European Union, which through the «Culture 2000» program finances the «Reconstruction» project, aimed at revitalizing the «Prison Regeneration in Europe» prisons. Currently, six European cities of Florence (Italy), Thessaloniki (Greece), Lancaster (England), the islands of Langholmen (Sweden), Bremen (Germany) and Porto (Portugal), having a similar experience, are combined through a website. Information on the restoration of obsolete historical penitentiary institutions is posted on the network. Florence has a coordinating role in this with the community.

In October 2013, the Murate Project was selected among the 100 best innovative urban projects and presented by the European Commission at the 100 Urban solutions exhibition as a useful example, best practices that will be disseminated at the European level [16].

\section{CONCLUSION}

For almost 5 centuries, the Santa Teresa, Santa Verdiana and Murate complexes were hidden from the city behind high walls and are practically not accessible to citizens, first used as monasteries and then as prisons. The implementation of projects for the revitalization of penitentiary complexes allowed the large area of the historical center of Florence to become an integral part of the city.

The updated complexes Santa Teresa, Santa Verdiana became the educational buildings of the faculty of architecture [17], which solved (compensated) the long-standing problem of the lack of educational facilities of Università degli Studi di Firenze.

The Murate social complex plays the role of a new urban public space, attracting numerous tourists, but most importantly, it meets the social and cultural needs of the inhabitants of Florence, providing them with municipal housing, and fulfilling educational and cultural functions. This project is a vivid example of the revitalization of isolated degraded territories located in the very center of a historic city where new construction is practically impossible.

\section{References}

[1] Santa Teresa, ed. by A. Breschi. Florence: DIDAPRESS, 2016, 127 p. [in Italian]. 
[2] R. Gatteschi, The ancient city prison, today a place for meetings and culture (L'antico carcere cittadino, oggi luogo d'incontri e di cultura). Informatore Unicoop Firenze. April 2014 https://www.coopfirenze.it/informatori/notizie/delitti-ecastighi?result=delitti\%20e\%20castighi accesed 24.11.2019 [in Italian].

[3] D. Pirro, Santa Verdiana. From dungeons to design. 02.04.2015, The Florentine. https://www.theflorentine.net/lifestyle/2015/04/santa-verdiana/ accesed 24.11.2019 [in Italian]

[4] Stinche - Stinche Prison, QWE.WIKI. https://it.qwe.wiki/wiki/Stinche_Prison accesed 24.11.2019 [in Italian].

[5] Recover the Murate. From prison to city. Popular residences, culture, commerce and public services, edited by V. Esposito (Recuperare le Murate. Da carcere a città. Residenze popolari, cultura, commercio e servizi pubblici). Florence, 2019, 112 p. [in Italian].

[6] G. Trotta, Le Murate: a microcosm in the heart of Florence (Le Murate: un microcosmo nel cuore antico di Firenze). Florence : Edizioni Comune aperto, 1999, p. 3 [in Italian].

[7] J. Cioni, Le Murate, short history of suffering stones (Le Murate, breve storia die pietre sofferenti). 13.09.2017, Florence City. https://www.florencecity.it/le-murate-breve-storia-pietresofferenti/ accesed 24.11.2019 [in Italian].

[8] C. Beccaria, Of crimes and penalties (Dei delitti e delle pene), 1764. Ed. by U. Mursia et al, 1973. Wikisource. https://it.wikisource.org/wiki/Dei_delitti_e_delle_pene accesed 24.11.2019 [in Italian].

[9] Prison and penalty (Il carcere e la pena). State archives, p. 3. Ristretti.

http://www.ristretti.it/commenti/2008/agosto/pdf1/carcere_pena. pdf accesed 24.11.2019 [in Italian].

[10] P. Ronchivecchi, The new penitentiary facility in Florence (Il nuovo stabilimento penitenziario in Firenze), 1843, p. 8, Wikisource.

https://it.wikisource.org/wiki/Il_nuovo_stabilimento_penitenzia rio_in_Firenze accesed 24.11.2019 [in Italian].

[11] RPBW, Roberto Melosi, Mario Pittalis. Le Murate. Divisare. https://divisare.com/projects/338285-rpbw-roberto-melosimario-pittalis-piermario-ruggeri-le-murate accesed 24.11.2019 [in Italian].

[12] Past: The recovery of the Murate (Passato: Il recupero delle Murate). Le Murate. Comune di Firenze. http://www.lemurate.comune.fi.it/lemurate/about/ accesed 24.11.2019 [in Italian].

[13] Mario Pittalis - Building recover ex-prison "Le Murate", Florence (2018, July 01). Premio Europeo di Architettura Matilde Baffa Ugo Rivolta. http://premiobaffarivolta.ordinearchitetti.mi.it/18-mario-pittalis/ accesed 24.11.2019 [in Italian].

[14] Florence - Murate (FIRENZE - Murate). 23.11.2018. CASA SPA. http://www.casaspa.it/informazioni/consegne/murate_12_5all.as $\mathrm{p}$ accesed 24.11.2019 [in Italian].

[15] G. Adinolfi, The vertical garden along the walls of the Murate (Il giardino verticale lungo le mura delle Murate). Firenze. La Repubblica. 27.07.2012. https://firenze.repubblica.it/cronaca/2012/07/27/news/il_giardin o_verticale_lungo_le_mura_delle_murate-39784029/ accesed 24.11.2019 [in Italian].

[16] EU, Le Murate chosen among the 100 best urban projects (Ue, Le Murate sceltotra i 100 migliori progetti urbani). 08.10.2013. Firenze. La Repubblica https://firenze.repubblica.it/cronaca/2013/10/08/news/ue_le_mu rate_scelto_tra_i_100_migliori_progetti_urbani-68186030/ accesed 24.11.2019 [in Italian].
[17] Santa Verdiana. 16.06.2015. L’Università degli Studi di Firenze. https://www.dida.unifi.it/vp-362-santaverdiana.html?newlang=eng accesed 24.11.2019 [in Italian]. 